\title{
Hubungan Antara Ekspresi P53 Mutan Terhadap Operabilitas Kanker Serviks Stadium IIB Pasca Kemoterapi Neoajuvan
}

\author{
${ }^{1}$ Nur Rohmah Arsyad, ${ }^{2}$ Risanto Siswosudarmo, ${ }^{3}$ Ardhanu Kusumanto \\ 1,2,3 Departemen Obstetri dan Ginekologi, Fakultas Kedokteran, Kesehatan Masyarakat dan Keperawatan UGM \\ Korespondensi: arsyad.rohmah@gmail.com
}

Submisi:28 Januari 2020; Revisi:18 Mei 2020; Penerimaan: 19 Mei 2020

\begin{abstract}
Background: The therapy for stage IIB cervical cancer according to FIGO is concurrent chemoradiation. The neoadjuvant chemotherapy followed by radical hysterectomy is an alternative therapy to improve the survival rate of cancer patients. Cervical cancer is mainly caused by the infection of Human Papilloma Virus (HPV), which contains protein E6 and E7 that downregulate the apoptotic function of p53. The absent of p53 wild-type and the present of p53 mutation play roles on the cervical cancer pathogenesis.

Objective: To analyze the association between the expression of mutant p53 to the stage IIB cervical cancer operability after neoadjuvant chemotherapy Method: This study was a prospective cohort, using 40 of 67 patient who met eligibility criteria. The parafin block from cervical tissue were processed for immunohistochemical staining of p53 using Anti-mutant p53 antibody [Y5] ab32049, Abcam, USA. Two study groups were assessed as: 1) weak and 2) strong expression of mutant $\mathrm{p} 53$ expression after neoadjuvant chemotherapy based on $\mathrm{H}$-score. Both group (weak and strong) were comparable in term of mutant p53 expression. In this study, the evaluation of operability was performed clinically. Age, BMI, histopathology, grade of differentiation, and regiment were also evaluated as the external variables. Chi square test, and logistic regression analysis were used for statistical analysis.

Results and Discussion: The rate of cervical cancer operability after chemotherapy was 19 out of 40 (47.5\%). The strong expression of mutant p53 was observed in 6 subjects (15\%). There was no significant association between weak vs strong expression of mutant p53 to the operability of the cancer (RR 1.5, Cl 95\% 0.46-4.88, p 0.45). Multivariate analysis showed that combination ( $50 \mathrm{mg} / \mathrm{m}^{2}$ dan 5 fluorourasil $450 \mathrm{mg} / \mathrm{m} 2$ ) was significantly correlated the operability (OR 7.02, Cl 95\% 1.27-40.07, p 0.03).

Conclusion: The expression of mutant p53 not correlate with operability after neoadjuvant chemotherapy, but combination regiment was.
\end{abstract}

Keywords: expression of mutant p53; stage IIB of cervical cancer; neoadjuvant chemotherapy; operability

\begin{abstract}
ABSTRAK
Latar Belakang: Tatalaksana kanker serviks stadium IIB sesuai rekomendasi FIGO adalah konkuren kemoradiasi. Tatalaksana kemoterapi neoajuvan yang dilanjutkan dengan histerektomi radikal merupakan tatalaksana alternaitf untuk memperbaiki harapan hidup secara keseluruhan. Patogenesis kanker serviks yang utama adalah infeksi virus Human Papilloma. Virus tersebut mempunyai protein E6 dan E7 yang akan menurunkan fungsi apoptosis p53. Menghilangnya fungsi p53 wild-type dan mutasi p53 berperan pada patogenesis kanker serviks.

Tujuan: Mengetahui hubungan ekspresi p53 mutan dengan operabilitas kanker serviks stadium IIB pasca kemoterapi neoajuvan

Metode: Penelitian merupakan penelitian kohort prospektif dengan 40 dari 67 pasien yang memenuhi kriteria kelayakan. Blok parafin jaringan serviks dipersiapkan untuk dilakukan pengecatan immunohistokimia dengan antibodi antimutan p53 [Y5] ab32049, Abcam, USA. Kelompok penelitian terdiri atas kelompok ekspresi p53 mutan lemah dan kuat berdasarkan $H$ score. Penilaian operabilitas dilakukan secara klinis. Variabel luar yang dievaluasi adalah usia, IMT, histopatologi, derajat diferensiasi, regimen, dan. Analisis data dengan uji Chi square dan uji regresi logistik

Hasil dan Pembahasan: Angka operabilitas pasca kemoterapi sebesar 47,5\%. Ekspresi kuat p53 mutan didapatkan pada 6 subyek (15\%). Tidak ada hubungan yang signifikan antara ekspresi p53 mutan lemah dan kuat terhadap operabilitas ( $00,45, \mathrm{RR} 1,5, \mathrm{Cl} 95 \%$ 0,46-4,88). Pengaruh variabel luar juga tidak signifikan secara statistik. Hasil analisis multivariat menunjukkan bahwa bahwa penggunaan regimen kombinasi (cisplatin (dosis $50 \mathrm{mg} / \mathrm{m}^{2}$ dan 5 fluorourasil $450 \mathrm{mg} / \mathrm{m}^{2}$ ) secara signifikan mempengrauhi operabilitas ( $p$ 0,03, OR 7,02, Cl 95\% 1,25-39,55).

Kesimpulan: Ekspresi p53 mutan tidak berhubungan dengan operabilitas pasca kemoterapi neoajuvan, namun regimen kemoterapi kombinasi menunjukkan hasil sebaliknya
\end{abstract}

Kata Kunci: ekspresi p53 mutan; kanker serviks IIB; kemoterapi neoajuvan; operabilitas 


\section{PENDAHULUAN}

Kanker serviks adalah kanker pada serviks atau mulut rahim. Kanker serviks merupakan kanker terbanyak kedua di seluruh dunia. ${ }^{1}$ Insidensi dan mortalitas kanker serviks sekitar 8-10/100.000 per tahun. ${ }^{2}$ Selama kurun waktu 50 tahun terjadi penurunan insidensi dan mortalitas akibat kanker serviks terutama tipe karsinoma sel skuamosa karena semakin baiknya sistem penapisan, menurunnya paritas, dan menurunnya prevalensi infeksi HPV (Human Papilloma Virus). ${ }^{3}$ Prevalensi kanker serviks di Indonesia sekitar 1,4 per 1000 penduduk dan merupakan penyebab kematian nomor 7 (5,7\%) dari seluruh kematian (Badan Penelitian dan Pengembangan Kesehatan Kementerian Kesehatan, 2013). Provinsi Kepulauan Riau, Maluku Utara, dan DI Yogyakarta menempati urutan tertinggi. ${ }^{5}$

Kanker serviks terkait dengan infeksi virus Human Papilloma (HPV) yang ditransmisikan melalui kontak seksual. Sekitar 90\% terkait dengan infeksi HPV, 70\% kanker serviks terkait dengan infeksi HPV tipe 16 dan $18 .{ }^{6}$ Perjalanan klinis kanker serviks bertahap, dimulai dengan lesi prakanker hingga lesi kanker invasif (World Health Organization, 2014). Virus Human Papilloma mempunyai banyak tipe. Tipe yang berisiko tinggi menyebabkan kanker serviks adalah tipe 16 dan 18. Tipe ini menghasilkan onkoprotein E6 dan E7. Onkoprotein E6 akan menyebababkan deregulasi fungsi normal p53, dan onkoprotein E7 akan mengambil alih regulasi siklus sel normal. ${ }^{6,8}$

Mutasi pada gen tumor supresor p53 diduga sebagai penyebab terjadinya kanker. Gen p53 mengkode pembentukan protein p53 yang terlibat dalam regulasi siklus sel. Sel normal terdapat p53 tipe wild yang akan menghentikan siklus sel pada fase $\mathrm{G} 1$ sehingga memberi waktu untuk perbaikan DNA sebelum proses replikasi, ataupun proses apoptosis kematian sel. Selain itu, gen p53 juga dapat mengalami mutasi genetik sehingga dapat menyebabkan memicu transformasi sel normal ke sel ganas (malignansi). Hilangnya p53 tipe wild atau adanya mutasi gen p53 akan menyebabkan aktivitas onkogenik. ${ }^{9-11}$ Ekspresi p53 mutan secara signifikan menunjukkan prognosis yang buruk pada kanker serviks. Ekpresi yang berlebih dari protein p53 mutan juga dapat dievaluasi dengan pengecatan immunohistokmia. P53 mutan menyebabkan aktivasi pertumbuhan gen pertumbuhan dengan kuat dan kontinu sehingga menghasilkan pertumbuhan sel yang tidak terkontrol dan onkogenesis. Dalam penelitian tersebut juga disimpulkan bahwa p53 merupakan prediktor independen terhadap prognosis kanker serviks. 12 Ekspresi p53 mengindikasikan prognosis yang buruk kanker serviks terutama pada ras Kaukasia. Sehingga evaluasi ekspresi p53 pada awal terapi dapat digunakan sebagai prediktor prognosis pasien kanker serviks. ${ }^{13}$

Tatalaksana alternatif pada stadium IB2, IIA2, dan IIB adalah kemoterapi neoajuvan dilanjutkan histerektomi radikal dengan atau tanpa radiasi. ${ }^{14}$ Kemoterapi neoajuvan berbasis platinum dengan dosis yang optimal (dosis lebih dari $25 \mathrm{mg} / \mathrm{m}^{2}$ persesi atau dosis total $100-320 \mathrm{mg} / \mathrm{m}^{2}$ ) dengan siklus pendek (kurang dari 14 hari). ${ }^{15}$ Kemoterapi neoajuvan ditujukan untuk mengecilkan massa tumor sehingga memfasilitasi dan mempermudah prosedur operatif dan memperbaiki luaran dibandingkan prosedur pembedahan saja. ${ }^{2,16,17}$

Divisi Ginekologi Onkologi RSUP dr. Sardjito Yogyakarta sudah menerapkan tatalaksana kemoterapi neoajuvan pada kanker serviks stadium IB2, IIA2 dan IIB. Hal ini karena terbatasnya fasilitas radioterapi. Kemoterapi neoajuvan pada stadium IIB dengan cancer free space $\geq 75 \%$ memungkinkan untuk tindakan operatif dan menekan progresivitas pertumbuhan sel. Operabilitas pasca kemoterapi neojuvan dievaluasi secara klinis.

Hingga saat ini belum diketahui secara pasti faktor yang mempengaruhi operabilitas pasca kemoterapi neoajuvan pada kanker serviks IIB. Penelitian yang dilakukan Prakoso pada tahun 2013, menyimpulkan bahwa ekspresi p53 mutan dan caspase 3 tidak mempengaruhi operabilitas. ${ }^{18}$ Peneliti ingin meneliti kembali dengan melihat pengaruh variabel - variabel lain yang berpengaruh terhadap operabilitas.

Berdasar penjelasan di atas, peneliti ingin mengetahui hubungan ekspresi p53 mutan terhadap operabilitas kanker serviks IIB pasca kemoterapi neoajuvan di RSUP dr. Sardjito Yogyakarta. 


\section{METODE}

Penelitian ini merupakan penelitian kohort. Penelitian ini menilai ekspresi p53 mutan secara immunohistokimia sebelum kemoterapi neoajuvan pada kanker serviks stadum IIB. Subyek dibagi dua kelompok berdasarkan ekspresi p53 mutan lemah dan kuat, lalu dinilai luaran operabilitas pasca kemoterapi neoajuvan.

Kriterian inklusi dan ekslusi subyek penelitian:

1. Kriteria inklusi adalah:

a. Pasien kanker serviks stadium stadium IIB yang menjalani kemoterapi neoajuvan.

b. Pasien selesai menjalani 3 siklus kemoterapi neoajuvan dengan interval 7 hari. Regimen kemoterapi neoajuvan yaitu regimen tunggal cisplatin $75 \mathrm{mg} / \mathrm{m}^{2}$ dan regimen kombinasi platinum $50 \mathrm{mg} / \mathrm{m}^{2}$ dan 5 fluorourasil $450 \mathrm{mg} / \mathrm{m}^{2}$.

c. Dapat dilakukan pengambilan data lengkap (data medis dan blok parafin jaringan patologi anatomi)

d. Bersedia berpartisipasi dalam penelitian dengan menandatangani informed consent.

2. Kriteria eksklusi:

a. Menderita kanker lain (ginekologi ataupun non ginekologi).

b. Mempunyai riwayat radioterapi primer untuk tatalaksana kanker serviks.

c. Mempunyai riwayat kemoterapi dengan regimen lain.

d. Terdapat penyakit penyerta (komorbid).

Penelitian dilakukan di Laboratorium Patologi Anatomi RSUP dr Sardjito Yogyakarta pada periode Januari 2016 - Maret 2017. Penelitian menggunakan blok parafin jaringan biopsi ataupun operasi yang tersimpan di Laboratorium Patologi Anatomi RSUP dr Sardjito dan Laboratorium Patologi Anatomi Waskitha. Blok parafin tersebut sebelumnya sudah disesuaikan dengan identitas pasien yang ikut dalam penelitian dengan memenuhi kriteria inklusi dan ekslusi. Selanjutnya dilakukan persiapan blok parafin untuk dilakukan pengecatan dengan antibodi antimutan p53 (anti-mutan p53 [Y5] (ab32049)). Penilaian ekspresi p53 dilakukan dengan cara semikuantitatif dengan menghitung skor histologis dari 5 lapang pandang dengan metode $\mathrm{H}$-score. Skor histoligis dihitung dengan menilai persentase dan intensitas sel yang tercat. Pengamatan ekspresi p53 mutan dilakukan dengan mikroskop pembesaran kuat (400x) pada lima lapang pandang berbeda oleh satu orang observer. Pengamatan dilakukan dengan menghitung persentase dan intensitas inti sel yang tercat oleh antibodi p53 mutan. Selanjutnya diambil rerata persentase dan intensitas dari kelima lapang pandang untuk dihitung derajat ekspresi dengan menggunakan $\mathrm{H}$-score.

Analisi data yang digunakan adalah analisi univariat, bivariat dan multivariat. Analisis yang digunakan adalah analisis Chi square $\left(X^{2}\right)$. Analisis multivariat yang digunakan adalah analisis regresi logistik prediktif.

\section{HASIL DAN PEMBAHASAN}

Dari 67 subyek yang direkrut, 27 tidak memenuhi kriteria inklusi sehingga diperoleh 40 subyek yang ikut dalam penelitian. Dari 40 subyek, sebanyak 19 subyek operable, dan 21 subyek inoperable pasca kemoterapi neoajuvan. Tabel 5 memaparkan komparabilitas antar kelompok. Kelompok usia terbanyak adalah diatas 45 tahun sebanyak 29 subyek (72,5\%). Status gizi, sebanyak 22 subyek (55\%) mempunyai status gizi normal (18,5-25 g/ $\left.\mathrm{m}^{2}\right)$. Histopatologi terbanyak adalah jenis skuamus sel karsinoma sebesar $77,5 \%$, sisanya merupakan tipe lain (adenokarsinoma, neuroendokrin, karsinoma clear cell). Derajat diferensiasi sel kanker diperoleh 25 subyek $(62,5 \%)$ subyek dengan derajat diferensiasi buruk. Regimen kemoterapi neoajuvan terbanyak yang digunakan adalah regimen tunggal dengan cisplatin sebesar $67,5 \%$.

Tabel 1 ini memaparkan bahwa dari 40 subyek didapatkan 34 subyek dengan ekspresi lemah p53 mutan, dimana persentase operabilitas seimbang antara kelompok operable dan inoperable. Ekspresi kuat p53 mutan hanya ditemukan pada 6 subyek, dan 4 subyek inoperable. Ekspresi lemah p53 mutan secara klinis meningkatkan operabilitas sebesar 1,5 kali dibandingkan kelompok ekspresi kuat, namun perbandingan kedua kelompok tersebut tidak bermakna secara statistik ( $p 0,45, \mathrm{RR} 1,5, \mathrm{Cl} 95 \%$ $0,46-4,88)$. 
Selain ekspresi p53 mutan, penelitian ini juga mengamati variabel luar yang dapat mempengaruhi operabilitas pasca kemoterapi neoajuvan. Variabel luar yang diamati pada penelitian ini adalah usia, IMT, jenis histopatologi, derajat diferensiasi sel kanker, dan regimen kemoterapi.

Tabel 3 memaparkan bahwa variabel usia secara statistik dan klinis tidak berpengaruh terhadap operabilitas ( 0 0,58, RR 0,82, Cl 95\% 0,42-1,61). Indeks massa tubuh secara statistik dan klinis juga tidak berpengaruh terhadap operabilitas $(p 0,16$, RR $0,74, \mathrm{Cl} 95 \%$ 0,38-1,41). Hasil yang sama juga terlihat pada histopatologi, dimana secara statistik dan klinis tidak berpengaruh terhadap operabilitas $(p 0,19$, RR 0,63, Cl 05\% 0,34-1,17). Derajat diferensiasi histopatologi tidak bermakna secara statistik, namun secara klinis derajat diferensiasi baik meningkatkan operabilitas sebesar 1,85 kali dibandingkan pada derajat diferensiasi buruk ( $p$ 0,06, RR 1,85, Cl 05\% $0,98-3,49)$. Jenis regimen yang digunakan pada kemoterapi neoajuvan juga tidak bermakna secara statistik dan klinis terhadap operabilitas, namun secara klinis meningkatkan operabilitas sebesar 1,87 kali ( $p$ 0,06, RR 1,87, Cl 95\% 1,01-3,44).

Tabel 1. Komparabilitas antar Kelompok

\begin{tabular}{|c|c|c|c|c|c|c|}
\hline \multirow{2}{*}{ Variabel } & \multicolumn{2}{|c|}{ Ekspresi p53 Mutan } & \multirow{2}{*}{$\begin{array}{c}\text { Ekspresi } \\
\text { Lemah (\%) }\end{array}$} & \multirow{2}{*}{$p$} & \multirow{2}{*}{$\mathrm{RR}$} & \multirow{2}{*}{$\mathrm{Cl} 95 \%$} \\
\hline & Lemah & Kuat & & & & \\
\hline \multicolumn{7}{|l|}{ Usia } \\
\hline$\geq 45$ tahun & 23 & 6 & 79,3 & 0,10 & 0,79 & $0,66-0,95$ \\
\hline$<45$ tahun & 11 & 0 & 100 & & 1 & \\
\hline \multicolumn{7}{|l|}{ IMT } \\
\hline$\leq 25 \mathrm{~kg} / \mathrm{m}^{2}$ & 17 & 5 & 77,3 & 0,13 & 0,81 & $0,63-1,05$ \\
\hline$>25 \mathrm{~kg} / \mathrm{m}^{2}$ & 17 & 1 & 94,4 & & 1 & \\
\hline \multicolumn{7}{|l|}{ Histopatologi } \\
\hline SCC & 27 & 4 & 87,1 & 0,49 & 1,12 & $0,77-1,63$ \\
\hline Non SCC & 7 & 2 & 77,8 & & 1 & \\
\hline \multicolumn{7}{|l|}{ Derajat diferensiasi } \\
\hline Baik & 14 & 1 & 93,3 & 0,25 & 1,17 & $0,92-1,48$ \\
\hline Buruk & 20 & 5 & 80,0 & & 1 & \\
\hline \multicolumn{7}{|l|}{ Regimen } \\
\hline Cisplatin+5FU & 11 & 2 & 84,6 & 0,96 & 0,99 & $0,75-1,31$ \\
\hline Cisplatin & 23 & 4 & 85,2 & & 1 & \\
\hline
\end{tabular}

Tabel 2. Hubungan antara Ekspresi p53 mutan dengan Operabilitas Pasca Kemoterapi Neoajuvan

\begin{tabular}{|c|c|c|c|c|c|c|}
\hline \multirow{2}{*}{$\begin{array}{l}\text { Ekspresi } \\
\text { p53 mutan }\end{array}$} & \multicolumn{2}{|c|}{ Operabilitas } & \multirow{2}{*}{$\begin{array}{l}\text { Operable } \\
\text { Rate (\%) }\end{array}$} & \multirow{2}{*}{$p$} & \multirow{2}{*}{ RR } & \multirow{2}{*}{ Cl 95\% } \\
\hline & Operable & Inoperable & & & & \\
\hline Ekspresi lemah & 17 & 17 & 50 & 0,45 & 1,5 & $0,46-4,88$ \\
\hline Ekspresi kuat & 2 & 4 & 33,3 & & 1 & \\
\hline
\end{tabular}




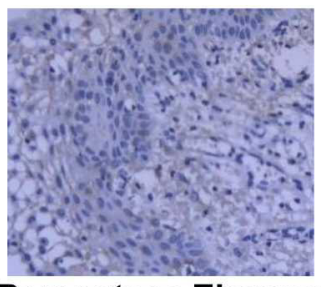

Persentase Ekspresi p53 0\%

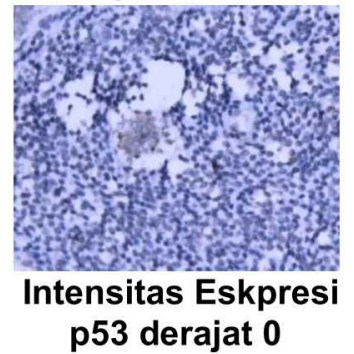

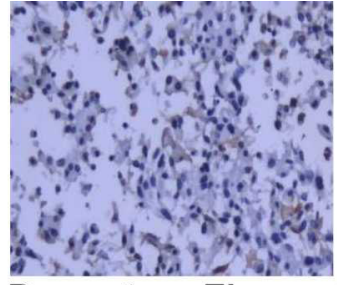

Persentase Ekspres p53 25\%

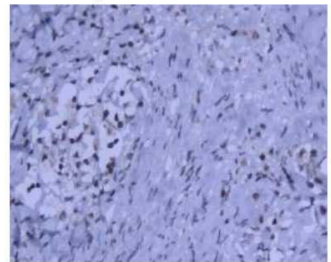

Intensitas Eskpresi p53 derajat 1

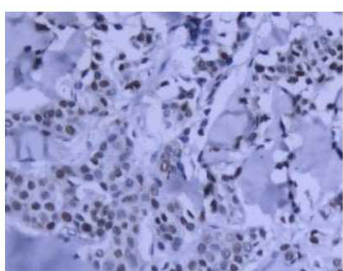

Persentase Ekspresi p53 50\%

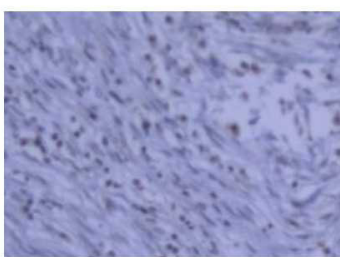

Intensitas Eskpresi p53 derajat 2

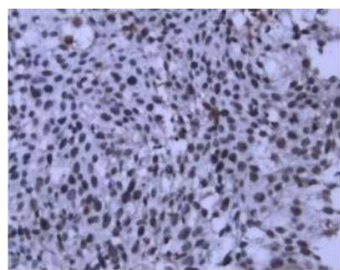

Persentase Ekspresi p53 75\%

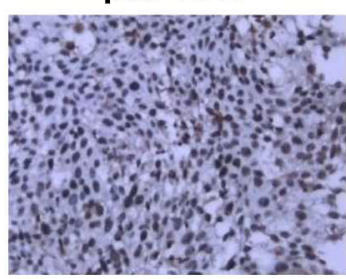

Intensitas Eskpresi

p53 derajat 3

Gambar 1. Ekspresi p53 mutan pada berrbagai Persentase dan Intensitas

Hasil analisis multivariat diperoleh bahwa ekspresi p53 mutan, IMT, jenis histopatologi, dan derajat diferensiasi berpengaruh bermakna secara statistik terhadap operabilitas pasca kemoterapi neoajuvan $(p>0,05)$. Regimen kemoterapi kombinasi (cisplatin dan 5 fluorourasil) secara statistik berpengaruh terhadap operabilitas $(p 0,03$, OR 7,02, Cl 95\% 1,25-39,55).

Tatalaksana standar kanker serviks stadium IIB berdasar rekomendasi National Cancer Institute dan International Federation of Gynecology and
Obstetrics (FIGO) adalah konkuren kemoradiasi. Terbatasnya fasilitas pelayanan radioterapi sehingga peneliti dan klinisi diberbagai dunia merumuskan tatalaksana alternatif untuk memperbaiki harapan hidup pasien. Tatalaksana alternatif yang banyak dilakukan adalah kemoterapi neoajuvan dilanjutkan histerektomi radikal. Meski demikian, beberapa Negara maju melakukan histerektomi radikal tanpa memberikan kemoterapi neoajuvan terlebih dahulu meski tatalaksana tersebut tidak sesuai dengan rekomendasi FIGO. 13,18,19

Tabel 3. Hubungan antara Variabel Luar dengan Operabilitas Pasca Kemoterapi Neoajuvan

\begin{tabular}{|c|c|c|c|c|c|c|}
\hline \multirow{2}{*}{ Variabel Luar } & \multicolumn{2}{|c|}{ Operabilitas } & \multirow{2}{*}{$\begin{array}{c}\text { Operable } \\
\text { Rate (\%) }\end{array}$} & \multirow{2}{*}{$p$} & \multirow{2}{*}{$\mathrm{RR}$} & \multirow{2}{*}{ Cl 95\% } \\
\hline & Operable & Inoperable & & & & \\
\hline \multicolumn{7}{|l|}{ Usia } \\
\hline$\geq 45$ tahun & 13 & 16 & 44,8 & 0,58 & 0,82 & $0,42-1,61$ \\
\hline$<45$ tahun & 6 & 5 & 54,5 & & 1 & \\
\hline \multicolumn{7}{|l|}{ IMT } \\
\hline$\leq 25 \mathrm{~kg} / \mathrm{m}^{2}$ & 9 & 13 & 40,9 & 0,16 & 0,74 & $0,38-1,41$ \\
\hline$>25 \mathrm{~kg} / \mathrm{m}^{2}$ & 10 & 8 & 55,6 & & 1 & \\
\hline \multicolumn{7}{|l|}{ Histopatologi } \\
\hline SCC & 13 & 18 & 41,9 & 0,19 & 0,63 & $0,34-1,17$ \\
\hline Non SCC & 6 & 3 & 66,7 & & 1 & \\
\hline \multicolumn{7}{|c|}{ Derajat diferensiasi } \\
\hline Baik & 10 & 5 & 66,7 & 0,06 & 1,85 & $0,98-3,49$ \\
\hline Buruk & 9 & 16 & 36,0 & & 1 & \\
\hline \multicolumn{7}{|l|}{ Regimen } \\
\hline Cisplatin-5FU & 9 & 4 & 69,2 & 0,06 & 1,87 & $1,01-3,44$ \\
\hline Cisplatin & 10 & 17 & 37 & & 1 & \\
\hline
\end{tabular}


Tabel 4. Analisis Multivariat Pengaruh antar Variabel terhadap Operabilitas Pasca Kemoterapi Neoajuvan

\begin{tabular}{lccc} 
Variabel & OR & Cl 95\% & Nilai $p$ \\
$\begin{array}{l}\text { p53 mutan } \\
\text { Lemah } \\
\text { Kuat }\end{array}$ & 1,35 & $0,15-11,71$ & 0,79 \\
IMT & 1 & & \\
$\leq 25 \mathrm{~kg} / \mathrm{m}^{2}$ & 2,55 & $0,53-12,34$ & 0,24 \\
$>25 \mathrm{~kg} / \mathrm{m}^{2}$ & 1 & & \\
$\begin{array}{l}\text { Histopatologi } \\
\text { SCC }\end{array}$ & 1,56 & $0,21-11,39$ & 0,66 \\
$\quad$ Non SCC & 1 & & 0,14 \\
$\begin{array}{l}\text { Derajat diferensiasi } \\
\text { Baik }\end{array}$ & 0,25 & $0,04-1,56$ & \\
$\quad$ Buruk & 1 & & 0,03 \\
Regimen NAC & & & \\
$\quad$ Cisplatin-5FU & $1,25-39,55$ & \\
$\quad$ Cisplatin & 7,02 & & \\
\hline
\end{tabular}

Prinsip kemoterapi neoajuvan adalah high dose-short cycle-lenght dengan regimen berbasis cisplatin. ${ }^{20,21}$ Kemoterapi neoajuvan juga memberikan harapan besar bagi wanita yang ingin mempertahankan fertilitasnya. Sebuah penelitian di Republik Ceko, melaporkan 10 pasien yang sukses mempertahankan fertilitas dan hamil meski luaran kehamilannya bervariasi. Dalam penelitian tersebut pasca kemoterapi neoajuvan dilakukan tindakan limfadenektomi secara laparoskopi dan trakelektomi simple transvaginal. ${ }^{16}$

Dalam penelitian ini angka operabilitas kanker serviks IIB pasca kemoterapi neoajuvan masih sangat rendah, yaitu hanya 47,5\% (19 dari 40 subyek). Penelitian - penelitian yang telah dipublikasikan melaporkan angka operabilitas pasca kemoterapi neoajuvan dapat mencapai $90 \% \cdot{ }^{18,22-24}$ Ekspresi p53 secara statistik tidak berpengaruh terhadap operabilitas kanker serviks IIB pasca kemoterapi neoajuvan ( $p 0,45, \mathrm{RR} 1,5, \mathrm{Cl} 95 \%$ 0,46-4,88). Hasil akhir analisis multivariat, regimen kombinasi secara signifikan mempengaruhi operabilitas ( $p 0,03, \mathrm{OR}$ 7,02, Cl 95\% 1,25-39,55).

Penelitian yang dilakukan oleh Yang et al (2016) dan Japan Clinical Oncology Group (JCOG 0102) tahun 2013 menyimpulkan bahwa kemoterapi neoajuvan tidak memperbaiki angka harapan secara keseluruhan, namun menurunkan kebutuhan radioterapi pasca histerktomi radikal. ${ }^{25,26}$ lla2, and IIb cervical cancer patients. Methods: A total of 219 patients were randomly assigned to two groups: 109 patients were treated with 1-2 cycles of chemotherapy (NACT group Kesimpulan yang berbeda dari penelitian $\mathrm{Hu}$ et al (2012) bahwa kemoterapi neoajuvan memperbaiki angka 5 tahun bebas penyakit (5 year disease free survival), ketahanan hidup keseluruhan, menurunkan durasi operasi, serta memberikan harapan preservasi fertilitas. ${ }^{27}$ Penelitian Chen et al (2008) menyimpulkan bahwa kemoterapi neoajuvan signifikan menurunkan ukuran tumor, mengeliminasi faktor risiko patologis, dan memperbaiki prognosis. ${ }^{28}$

Dalam penelitian ini, ekspresi p53 mutan secara statistik dan klinis tidak signifikan berhubungan dengan operabilitas kanker serviks stadium IIB pasca kemoterapi neoajuvan ( $p 0,45, \mathrm{RR} 1,5, \mathrm{Cl} 95 \%$ 0,46$4,88)$. Hasil ini tidak sejalan dengan penelitian Liu et al (2015) dan Sandhu \& Shivakumar (2017) yang menyimpulkan bahwa ekspresi p53 merupakan faktor prognosis buruk terhadap kanker serviks. ${ }^{1,10}$ Overexpression p53 mutan ditemukan bermakna pada ras Kaukasia, tidak pada ras Asia. Mutasi gen p53 mutan hanya terdeteksi sebesar 11,6\% kanker serviks jenis karsinoma sel skuamoma, namun ekspresinya tidak selalu ditemukan. ${ }^{13}$

Penelitian yang dilakukan oleh Prakosa pada tahun 2013 di RSUD dr Soetomo Surabaya memperoleh hasil yang sama. Penelitian tersebut 
meneliti ekpresi p53 dan caspase 3 yang secara bersama - sama diteliti untuk mencari prediktor operabilitas. ${ }^{18}$ Keduanya secara statistik tidak bermakna. Regimen kemoterapi dalam penelitian tersebut berbeda dengan penelitian ini. Hasil penelitian sama dengan penelitian ini. Hal tersebut dapat disebabkan beberapa hal:

1. Tidak ada mutasi pada gen p53, tetapi fungsi p53 wild type terganggu karena onkogen E6 HPV menginaktifkan gen p53.

2. Induksi B-cell lymphoma-extra large (Bcl-XL) oleh onkogen E7 HPV sehingga proses apoptosis terganggu.

3. Resistensi terhadap regimen kemoterapi.

4. Ekspresi p53 mutan hanya mampu terdeteksi sebesar $11,6 \%$ pada tipe karsinoma sel skuamosa.

Tipe histopatologi karsinoma sel skuamosa mempunyai prognosis yang lebih baik. Karsinoma sel skuamosa merupakan tumor kemosensitif dan mempunyai respon kemoterapi neoajuvan yang baik dibandingkan adenokarsinoma. ${ }^{11,28}$ Dalam penelitian ini karsinoma sel skuamosa secara statistik dan klinis tidak berpengaruh terhadap operabilitas ( $p$ 0,19, RR 0,63, Cl 95\% 0,34-1,17). Hal tersebut dapat disebabkan oleh jumlah ukuran sampel yang kecil, dibutuhkan penelitian dengan sampel yang besar dengan kontrol bias yang baik.

Derajat diferensiasi sel kanker tidak terbukti secara signifikan memperngaruhi operabilitas. Derajat diferensiasi baik meningkatkan operabilitas sebesar 1,8 kali dibandingkan kelompok dengan derajat difernsiasi buruk ( $p$ 0,06, RR 1,85, Cl 95\% $0,98-3,49)$. Hasil penelitian ini sejalan dengan penelitian Chen et al (2008). ${ }^{21}$

Hasil analisis multivariat dalam penelitian ini menunjukkan bahwa regimen kombinasi (cisplatin $50 \mathrm{mg} / \mathrm{m} 2$ dan 5 fluorourasil $450 \mathrm{mg} / \mathrm{m} 2$ ) secara statistik bermakna meningkatkan operabilitas ( $p$ 0,03, OR 7,02, Cl 95\% 1,25-39,55). Regimen kemoterapi neoajuvan yang digunakan di RSUP $\mathrm{dr}$ Sardjito belum seragam yaitu regimen tunggal cisplatin $75 \mathrm{mg} / \mathrm{m}^{2}$ dan kombinasi cisplatin-5FU (cisplatin $50 \mathrm{mg} / \mathrm{m}^{2}$ dan 5 fluorourasi $450 \mathrm{mg} / \mathrm{m}^{2}$. Sesuai dengan penjelasan di atas bahwa prinsip kemoterapi neoajuvan adalah dosis tinggi dengan siklus pendek (high dose, short cycle-length) dengan regimen berbasis cisplatin. ${ }^{16,21}$ Dalam penelitian ini sangat mungkin terjadi bias karena regimen yang digunakan berbeda antar kelompok.

Hingga saat ini belum ada regimen baku dalam tatalaksana kemoterapi neoajuvan pada kanker serviks. Terdapat variasi dalam berbagai penelitian dengan hasil yang bervariasi pula. Beberapa regimen kemoterapi neoajuvan yang digunakan diberbagai penelitian:

1. Paclitaxel - cisplatin (paclitaxel $175 \mathrm{mg} / \mathrm{m}^{2}$ dan cisplatin $75 \mathrm{mg} / \mathrm{m}^{2}$ atau carboplatin AUC 5) diberikan siklus 3 minggu sebanyak 3 kali. Regimen ini digunakan di RSUD dr Soetomo Surabaya. ${ }^{18}$

2. Paclitaxel - cisplatin (paclitaxel $175 \mathrm{mg} / \mathrm{m}^{2}$ dan cisplatin $100 \mathrm{mg} / \mathrm{m}^{2}$ ) diberikan siklus $3 \mathrm{minggu}$ sebanyak 3 kali. Regimen ini telah digunakan dalam penelitian Angioli et al di Italia pada tahun 2012. ${ }^{29}$

3. Cisplatin - ifosfamid (cisplatin $75 \mathrm{mg} / \mathrm{m}^{2}$ ifosfamid $2 \mathrm{~g} / \mathrm{m}^{2}$ ) untuk jenis karsinoma sel skuamosa, dan cisplatin-doxorubicin (cisplatin $75 \mathrm{mg} / \mathrm{m}^{2}$ dan doxorubicin $35 \mathrm{mg} / \mathrm{m}^{2}$ ) untuk jenis adenokarsinoma dosis perminggu dan diberikan $3-4$ siklus. ${ }^{16}$

4. BOMP (bleomicin $7 \mathrm{mg}$ hari $1-5$, vincristin 0,7 $\mathrm{mg} / \mathrm{m}^{2}$ hari 5 , mitomicin $7 \mathrm{mg} / \mathrm{m}^{2}$ hari 5 , dan cisplatin $14 \mathrm{mg} / \mathrm{m}^{2}$ hari $1-5$ ) siklus 3 minggu, 2-4 siklus. Regimen ini digunakan dalam JCOG 0102 tahun 2013. ${ }^{25}$

5. Irinotecan dan cisplatin (irinotecan $60 \mathrm{mg} / \mathrm{m}^{2}$ pada hari 1,8, dan 15 - cisplatin $70 \mathrm{mg} / \mathrm{m}^{2}$ pada hari 1). Regimen ini digunakan pada penelitian multisenter di China tahun 2015. ${ }^{26} \mathrm{lla2}$, and IIb cervical cancer patients. Methods: A total of 219 patients were randomly assigned to two groups: 109 patients were treated with 1-2 cycles of chemotherapy (NACT group

Saat ini sedang berlangsung penelitian skala besar yang dilakukan oleh EORTC (European Organisation for Research and Treatment of Cancer) sejak 2013 dan sampai saat ini telah sampai pada fase III. Penelitian tersebut membandingkan kelompok kemoterapi neoajuvan plus histerektomi radikal dan kelompok radioterapi. Penelitian ini masih berlanjut sampai dengan 2019 untuk menilai ketahanan 
hidup 5 tahun ( 5 years survival) Penelitian tersebut memberikan harapan besar terhadap kelanjutan kemoterapi neoajuvan dalam tatalaksana kanker serviks locally advanced (stadium IB2, IIA2, dan IIB).

\section{KESIMPULAN DAN SARAN}

Ekspresip53 mutantidaksignifikan berhubungan dengan operabilitas kanker serviks IIB pasca kemoterapi neoajuvan (OR 1,35), tetapi regimen kemoterapi kombinasi (cisplatin dan 5 fluorourasil) lebih berpengaruh terhadap operabilitas (OR 7,02).

\section{DAFTAR PUSTAKA}

1. Liu L, Li XD, Chen HY, Cui JS, Xu DY. Significance of Ebp1 and p53 protein Expression in Cervical Cancer. Genet Mol Res. 2015;14(4):11860-6.

2. Di Saia PJ, Creasman WJ. Clinical Gynecologic Oncology. Eight Edit. Philadelphia: Elsevier Saunders; 2012.

3. Karlan BY, Brostow RE, Li AJ. Gynecologic Oncology Clinical Practice \& Surgical Atlas. Journal of Chemical Information and Modeling. McGraw-Hill Company; 2013. 1689-1699 p.

4. Badan Penelitian dan Pengembangan Kesehatan Kementerian Kesehatan. Riset Kesehatan Dasar (RISKESDAS) 2013. 2013;

5. Kementrian Kesehatan RI Pusat Data dan Informasi Kesehatan. Situasi Penyakit Kanker. infodatin-Stop Kanker. 2015; hal 3.

6. Saha SK, Khuda-Bukhsh AR. Berberine alters Epigenetic Modifications, Disrupts Microtubule Network, and Modulates HPV-18 E6-E7 Oncoproteins by Targeting p53 in Cervical Cancer cell HeLa: A Mechanistic Study Including Molecular Docking. Eur J Pharmacol

7. World Health Organization. Comprehensive Cervical Cancer Control A Guide to Essential Practice [Internet]. WHO Library Cataloguing-in-Publication Data. 2014.

8. Ikuta A, Saito J, Mizokami T, Nakamoto T, Yasuhara M, Nagata F, et al. Correlation p53 Expression and Muman Papilloma Virus Deoxyribonucleic Acid with Clinical Outcome in Early Uterine Cervical Carcinoma. Cancer Detect Prev. 2005;29(6):528-36.

9. Habbous S, Pang V, Eng L, Xu W, Kurtz G, Liu FF, et al. p53 Arg72Pro Polymorphism, HPV Status and Initiation, Progression, and Development of Cervical Cancer: A Systematic Review and Metaanalysis. Clin Cancer Res. 2012;18(23):6407-15.
10. Sandhu JK, Shivakumar S. Study of p53 in Cervical Intraepithelial Neoplasia and Carcinoma Cervix with Clinico-pathological Correlation. Int J Sci Study. 2016;4(1):208-14.

11. Thakrar M, Mathur K. Immunohistochemical Study of p53 Expression as Proliferative Index in Neoplasia of the Uterine Cervix. Int Arch Integr Med [Internet]. 2017;4(12):16-25. Available from: http:// iaimjournal.com

12. Oh MJ, Choi JH, Lee YH, Lee JK, Hur JY, Park YK, et al. Mutant p53 Protein in the Serum of Patients with Cervical Carcinoma: Correlation with the Level of Serum Epidermal Growth Factor Receptor and Prognostic Significance. Cancer Lett [Internet]. 2004;203(1):107-12.

13. Zhou R, Wei C, Liu J, Luo Y, Tang W. The Prognostic Value of p53 Expression for Patients with Cervical Cancer: A Meta Analysis. Eur J Obstet Gynecol Reprod Biol [Internet]. Elsevier Ireland Ltd; 2015;195:210-3.

14. Wiebe E, Denny L, Thomas G. FIGO Cancer Report 2012 Cancer of the Cervix Uteri. Int J Gynecol Obs. 2012;2:100-9.

15. Tierney J., Neoadjuvant Chemotherapy for Cervical Cancer Meta-analysis Collaboration (NACCMA) Collaboration, L R. Neoadjuvant Chemotherapy for Locally Advanced Cervix Cancer ( Review ). Cochrane Collab [Internet]. 2015;(2):1-42.

16. Robova H, Rob L, Halaska MJ, Pluta M, Skapa P, Strnad P, et al. High-Dose Density Neoadjuvant Chemotherapy in Bulky IB Cervical Cancer. Gynecol Oncol [Internet]. Elsevier Inc.; 2013;128(1):49-53

17. Rydzewska L, Tierney J, Vale CL, Symonds PR. Neoadjuvant Chemotherapy Plus Surgery Versus Surgery for Cervical Cancer. Cochrane database Syst Rev [Internet]. 2012;12(12):CD007406.

18. Prakosa T, Askandar B, Fauziah D. Ekspresi p53 Mutan dan Caspase 3 sebagai Faktor Prediksi terhadap Operabilitas Kanker Serviks IIB setelah Mendapat Kemoterapi Neoadjuvan. Indones J Cancer. 2013;7(2):61-7.

19. Kasamatsu T, Onda T, Sawada M, Kato T, Ikeda S. Radical Hysterectomy for FIGO stage IIB Cervical Cancer: Clinicopathological Characteristics and Prognostic Evaluation. Gynecol Oncol [Internet]. Elsevier Inc.; 2009;114(1):69-74.

20. Robova H, Halaska MJ, Pluta M, Skapa P, Matecha J, LisyJ, et al. Oncological and Pregnancy Outcomes after High-Dose Density Neoadjuvant Chemotherapy and Fertility-Sparing Surgery in Cervical cancer. Gynecol Oncol [Internet]. Elsevier Inc.; 2014;135(2):213-6

21. Chen $M-B$, Zhu $Y-Q, X u J-Y$, Wang $L-Q$, Liu $C-Y$, Ji Z-Y, et al. Value of TP53 Status for Predicting Response to Neoadjuvant Chemotherapy in Breast 
Cancer: a meta-analysis. PLoS One [Internet]. 2012;7(6):e39655-e39655.

22. Kim HS, Sardi JE, Katsumata N, Ryu HS, Nam JH, Chung $\mathrm{HH}$, et al. Efficacy of Neoadjuvant Chemotherapy in Patients with FIGO Stage IB1 to IIA Cervical Cancer: An International Collaborative Metaanalysis. Eur J Surg Oncol [Internet]. Elsevier Ltd; 2013;39(2):11524

23. Qin T, Zhen J, Zhou M, Wu H, Ren R, Qu B, et al. Efficacy of Neoadjuvant Chemotherapy Plus Radical Surgery in Patients with Bulky Stage II Cervical Squamous Cell Carcinoma: A Retrospective Cohort Study. Int J Surg [Internet]. 2016;30:121-5.

24. Scandurra G, Scibilia G, Banna GL, D???Agate G, Lipari $\mathrm{H}$, Gieri $\mathrm{S}$, et al. Efficacy and tolerability of paclitaxel, ifosfamide, and cisplatin as a neoadjuvant chemotherapy in locally advanced cervical carcinoma. J Gynecol Oncol. 2015;26(2):118-24.

25. Katsumata N, Yoshikawa H, Kobayashi H, Saito T, Kuzuya K, Nakanishi T, et al. Phase III Randomised Controlled Trial of Neoadjuvant Chemotherapy plus Radical Surgery vs Radical Surgery alone for Stages IB2, IIA2, and IIB Cervical Cancer: a
Japan Clinical Oncology Group Trial ( JCOG 0102 ). $\mathrm{Br} J$ Cancer [Internet]. Nature Publishing Group; 2013;108(10):1957-63.

26. Yang Z, Chen D, Zhang J, Yao D, Gao K, Wang H, et al. The Efficacy and Safety of Neoadjuvant Chemotherapy in The Treatment of Locally Advanced Cervical Cancer: A Randomized Multicenter Study. Gynecol Oncol. 2015;141:231-9.

27. Hu T, Li S, Chen Y, Shen J, Li X, Huang K, et al. Matched-case Comparison of Neoadjuvant Chemotherapy in Patients with FIGO Stage IB1-IIB Cervical Cancer to Establish Selection Criteria. Eur J Cancer. 2012;48:2353-60.

28. Chen H, Liang C, Zhang L, Huang S, Wu X. Clinical Efficacy of Modified Preoperative Neoadjuvant Chemotherapy in the Treatment of Locally Advanced (Stage IB2 to IIB) Cervical Cancer: Randomized Study. Gynecol Oncol [Internet]. Elsevier Inc.; 2008;110(3):308-15.

29. Angioli R, Plotti F, Montera R, Aloisi A, Luvero D, Capriglione $S$, et al. Neoadjuvant Chemotherapy plus Radical Surgery Followed by Chemotherapy in Locally Advanced Cervical Cancer. Gynecol Oncol [Internet]. Elsevier Inc.; 2012;127(2):290-6. 